\title{
SOCIAL AND ECONOMIC ASPECTS OF THE HUMAN SECURITY CONCEPT
}

\author{
Meri Boshkoska* \\ Faculty of Economics, Prilep, University St. Kliment Ohridski, Bitola, \\ The Former Yugoslav Republic of Macedonia
}

The objective of this work is to analyze the real state in the field of the Macedonian Health and Social Policy, the pension system and human security at work. This type of analysis will make it possible to deduce certain conclusions and recommendations about accomplishing a higher level of general human security in the Former Yugoslav Republic of Macedonia. The results of this study enable us to conclude that, in the Former Yugoslav Republic of Macedonia, living expenses have been permanently increased, the unemployment rate is high and the average minimum wages paid in the region are the lowest, which all contributes to profound poverty in the country. It is also necessary to revise the laws and regulations in the field of workers' health and security, make urgent changes in order to ensure the sustainability of the pension system and also start the reforms that will provide a sustainable and efficient health care system.

Keywords: pension system, social security, poverty rate, health care system

\section{JEL Classification: I31, I32, H55}

\section{INTRODUCTION}

In order to make our contribution to a better understanding of the human security concept and its successful introduction and practical use in the Former Yugoslav Republic of Macedonia (FYR Macedonia), the limelight of this work is to study the real state of social living as well as the legislation

\footnotetext{
* Correspondence to: M. Boshkoska, Faculty of Economics, Prilep, University St. Kliment Ohridski, Bitola, Marksova bb, 7500 Prilep, The Former Yugoslav Republic of Macedonia; e-mail:meribb@yahoo.com
}

and the institutions of the FYR Macedonia whose subjects of work are: health and social insurance, pension insurance and human security at work. The analysis of the achieved results will help to offer recommendations for the improvement of the conditions in the previously mentioned fields, which are quite important if we want to reach general human security.

Having in mind the objective of the study, the main hypotheses of our research are as follows: It is essential to implement profound reforms in the Macedonian Health and Social Sectors, the Pension 
System and in the field of human security at work in order to achieve a higher level of general human security in the FYR Macedonia.

The research methodology consists of a combination of different methodological aspects based on:

- a content analysis of various institutional documents and research papers dealing with human security, a pension system analysis, social and health safety and health and safety at work;

- using administrative databases and numerical data for the purpose of explaining the research issues;

- a deduction approach will be applied through the content analysis.

The rest of the paper is structured as follows: in the second section, a literature review is presented, focusing on understanding the meaning of the human security concept. In the third section, the results of the current situation and the legislative framework in the areas of security and health at work, social and health protection and the state and the problems in the pension system of the FYR Macedonia are presented. In the fourth section, the research results are subjected to discussion. The last section of the paper presents the conclusion of the study.

\section{LITERATURE REVIEW}

There are various definitions of the human security concept, depending on the starting point of their explanation. S. Stanarevic $(2014,10)$ emphasizes the fact that, first of all, a distinction between national and human security should be made. Human security is the concept that refers to people and the community, not to countries and their territories. This author points out the explanation of the United Nations Organization (UNDP) from 1994, according to which human security is a concept oriented towards humans, the basic element of which is our becoming free from fear and poverty. According to R. Thakur (1997, 53-54), social and political empowerment, economic growth and improved access to resources are among the factors that can influence the improvement of human security. K. Anan (UNESCO, 1999, 15) points out that human security could no longer be explained by military terms. In itself, it includes economic development, social justice, environment protection, democratization, disarmament, respecting human rights and the rule of law. According to S. Ogata (1998), human security consists of several key elements, namely:

- an opportunity for all citizens to live in peace and securely within the state borders;

- people should enjoy their rights and obligations (human, political, social, economic and cultural rights) with no discrimination;

- social inclusion or the same approach to political, social and economic politics;

- rule of law and an independent legal system.

In the 1994 Human Development Report (UNDP, 1994, 22-23), the UNDP points out the two main aspects of human security:

- security against famine, diseases and repression, and

- protection from sudden, harmful disorders in a human's everyday life.

The said report emphasizes the fact that human security could be analyzed from the seven categories (UNDP, 1994, 24-25): economic security, health security, food security, environmental security, personal security, political security and community security.

A. Devon (2014) sums up that human security concept also includes challenges people face on a daily basis, such as job security, education opportunities, social and cultural freedoms. 
P. Veselinovic (2014) states that in order to improve the quality of life in the Republic of Serbia, it is necessary that structural reforms in the pension, social security and healthcare systems be undertaken.

Various definitions of the human security concept indicate the necessity of having an integral perception of human security in order to prevent it from disseminating in different directions (Sokov, 2012).

Opinions similar to these suggest that the human security concept includes the important elements of social living that allow a high level of citizens' quality and secure life.

\section{AN ANALYSIS OF THE STATE OF AND THE LEGAL REGULATION IN THE PENSION, SOCIAL AND HEALTH FIELDS, AS WELL AS THE WORK RELATIONSHIPS}

\section{Security and Health at Work}

Security and health at work is an interdisciplinary concept dealing with prevention from professional risks connected to every work activity. The main objective of this concept is to induce and maintain the highest level of security and health at work, that is to say providing conditions to prevent and protect workers from occupational risks (Alli, 2008, 20).

In the FYR Macedonia, workers' security and health are regulated by the following laws (Grozdanovski et al, 2015, 7): Security and Health at Work Law; Working Relationships Law; Health Protection Law; Pension and Disablement Insurance Law; Law on Protection from Disturbance at Work; Labor Evidence Law; Health Insurance Law; Labor Inspection Law.

From the aspect of regulating Security and Health at Work Conditions, the existence of the abovementioned law, as well as numerous subordinate legislation acts, a picture has been created in which the security and health of employers in the FYR Macedonia has been provided. However, in the FYR Macedonia, there is an insufficient provision of workers' security and health of at work (Grozdanovski et al, 2015, 8-9). It is confirmed by the data in the annual reports of the State Inspectorate, according to which a remarkable and continuous increase in body injuries is noticeable in 2010, 2011 and 2012. In 2010, 625 injuries at work were recorded; in 2011, their number was 786, whereas in 2012, the total number of the registered injuries at work was amounted to 1446 (State Labor Inspectorate - SLI, 2016). These data confirm the ranking of the countries in this field, done by the European Foundation for the Improvement of the Life and Work Conditions (EUROFOUND).

In the EUROFOUND research, the FYR Macedonia is the country with the highest level of exposure to physical risks. This research included 34 countries and 44,000 workers in the period from January to June 2010. The research is conducted every five years and the results are estimated on the basis of a representative sample of European workers, not on the basis of the whole of the population. The data show that a great number of injuries which often end with fatal consequences upon a human life and inappropriate conditions and carelessness with respect to workers' health cause long-term social problems that affect workers' ability. This conclusion leads to a need for measures and activities of the institutions responsible for doing so, by which the existing risks at work will be decreased. This will provide higher security for the employed and better working conditions.

In the recommendations part, the measures and activities that could contribute to an improvement of the state in the field of security and health at work in our country will be pointed out. 


\section{Social and Health Protection}

The social and health protection of citizens have been an important segment of the rule of the Government. The social policy term has been used in order to mark governmental policies for the realization of welfare and social protection, as well as the ways in which welfare in a society is achieved (Spicker, 2000, 111-112).

„Social safety refers to the services provided by the social state in many kinds and forms designed for the protection of citizens" (Pejkovski \& Majovski, n.d, 113).

Social protection is a system of measures, activities and policies for preventing and overcoming the basic social risks citizens are exposed to during their lives, for decreasing poverty and social exclusion, and for strengthening the citizen's capacity for his/her own protection (Law on Social Protection, Article 2, 2009, 1).

The Ministry of Labor and Social Politics is the central institution that creates policies, strategic planning, administration and monitoring of the realization and application of laws and regulations in the field of social protection in the FYR Macedonia. The Government of the FYR Macedonia hands down the National Program for Social Protection Development, which defines the objectives, priorities and directions of the development of social protection for citizens (MLSP, 2010, 8).

The Social Protection System in the FYR Macedonia is the system of measures, activities and policies for the prevention of and exceeding the basic social risks citizens are faced with during their lives. The basic social risks include: health risks, the risk of aging and becoming old, the single parent risk, the unemployment risk, the poverty risk and other kinds of social exclusions (PWC, 2014, 211).
The Social Security Law settles the system and organization of social protection, social protection rights, financing and the procedure of the realization of social protection rights ("Social Protection Law", Article 2, 2009, 1).

Among other laws falling within the field of social protection in the FYR Macedonia, there are the following ones as well: The Family Law; The Asylum and Temporary Protection Law; The Disability Organizations Law and other laws.

The existence of an appropriate legal regulation and reform processes in the field of social protection is not sufficient to improve the social state of almost one-half of citizens in our country. This has been confirmed by numerous inland and foreign studies as well as by the State Statistical Office (SSO) of the FYR Macedonia. The Income and Living Conditions Poll is an annual research study carried out by the State Statistical Office and a source of data on poverty and social exclusion. According to the data about income and living conditions obtained from this poll, the State Statistical Office estimates the so-called Laeken indicator of the poverty rate. In 2015, the rate of poverty-stricken individuals in the FYR Macedonia was $21.5 \%$ of the total population, i.e. 457,000 individuals (State Statistical Office, 2016, 35). This means that these individuals can be categorized into at least one of the following situations:

- a poverty risk, after social transfers;

- socially and materially deprived individuals;

- individuals who live in households with very low work intensity.

The fact that the greatest number of citizens who live in the FYR Macedonia are faced with poverty is shown in Figure 1, where a comparison between the poverty rate, i.e. social exclusion in the FYR 


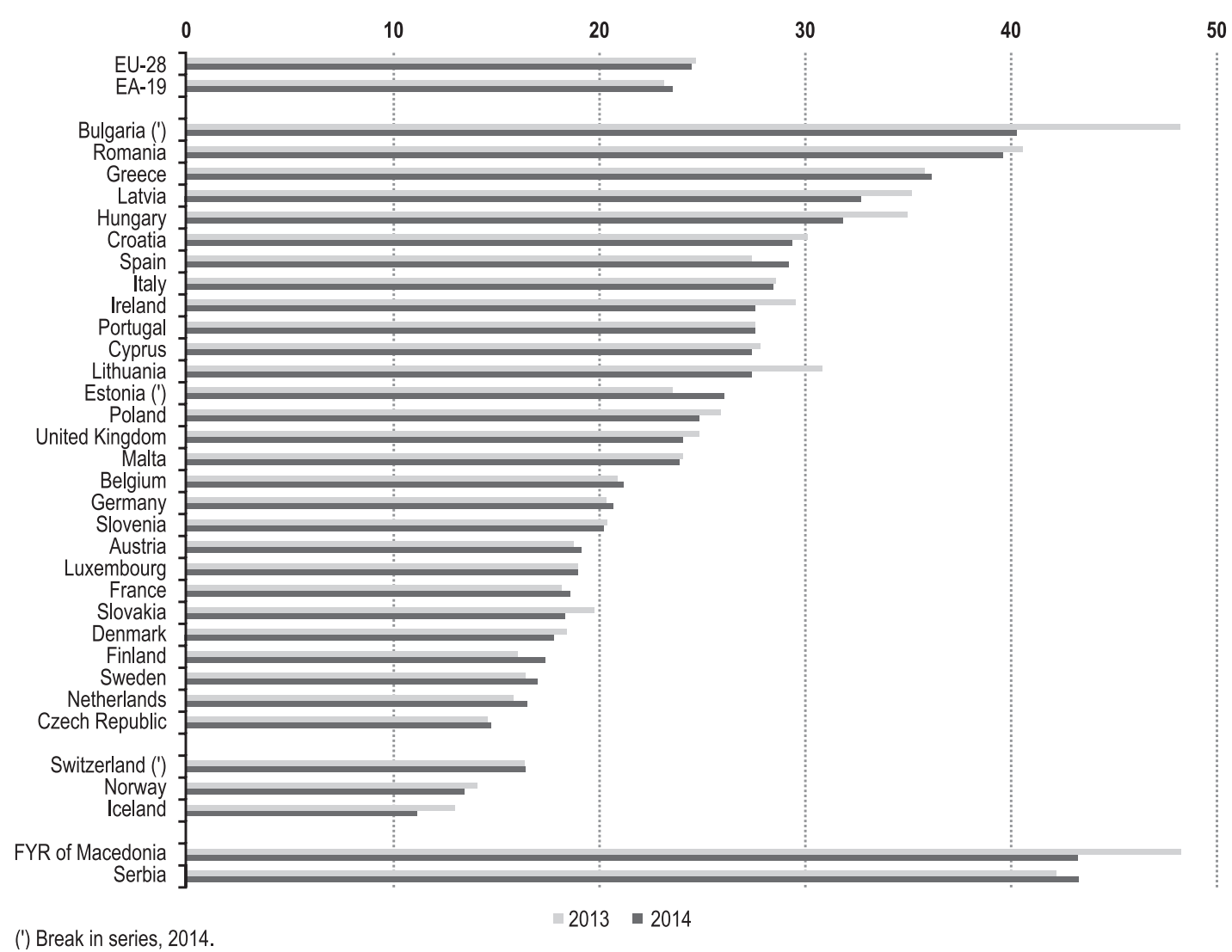

Figure 1 Poverty or Social Exclusion Rate, 2013 and 2014

Source: Eurostat statistics, 2016a

Macedonia, on the one hand, and that of the European Union (EU), on the other, is presented. According to the diagram data, in 2014, the FYR Macedonia was at the top of the list of the citizens who have faced poverty.

Living expenses have a great impact on an increase in the poverty rate. According to the COICOP Classification, the Cost of Living Index was annually increased by $2.8 \%$ in 2013 . Table 1 accounts for the costs of living index of some important groups.

According to the data demonstrated in this chart, an increase in prices is noticed in the groups of: health, education, alcoholic drinks, clothes and footwear, soft drinks, other goods and services, furniture, household goods and maintenance of the household goods and housekeeping, water, electricity, gas and other fuels. A decrease in prices is noticed in the Communication and Transport Sector, Recreation and Culture (State Statistical Office, 2014, 31).

The Cost of Living Index in the FYR Macedonia is presented in Figure 2. It could be noticed that, in the period from 2004 to 2013, the Cost of Living Index permanently increased, which had an impact on the poverty rate in that the same made it increase. 
Table 1 The Cost of Living Index Classification according to COICOP

\begin{tabular}{l|ccc}
\hline & 2011 & 2012 & 2013 \\
\hline Total & 103.9 & 103.3 & 102.8 \\
\hline $\begin{array}{l}\text { Food and non-alcoholic } \\
\text { beverages }\end{array}$ & 106.2 & 102.3 & 103.4 \\
$\begin{array}{l}\text { Alcoholic beverages, } \\
\text { tobacco }\end{array}$ & 101.0 & 100.2 & 104.0 \\
$\begin{array}{l}\text { Clothes and shoes } \\
\text { Housing, water, } \\
\text { electricity, gas and other } \\
\text { fuels }\end{array}$ & 101.4 & 105.4 & 107.0 \\
$\begin{array}{l}\text { Furnishings, household } \\
\text { equipment, maintenance of } \\
\text { the house }\end{array}$ & 100.9 & 101.0 \\
$\begin{array}{l}\text { Health } \\
\text { Transport }\end{array}$ & 103.8 & 103.0 & 108.4 \\
$\begin{array}{l}\text { Communication (PTT } \\
\text { services) }\end{array}$ & 105.3 & 106.3 & 99.3 \\
Recreation and culture & 98.3 & 95.8 & 99.0 \\
$\begin{array}{l}\text { Education } \\
\text { Restorants and hotels }\end{array}$ & 99.1 & 98.6 & 97.9 \\
Other goods and services & 104.3 & 103.6 & 106.6 \\
\hline
\end{tabular}

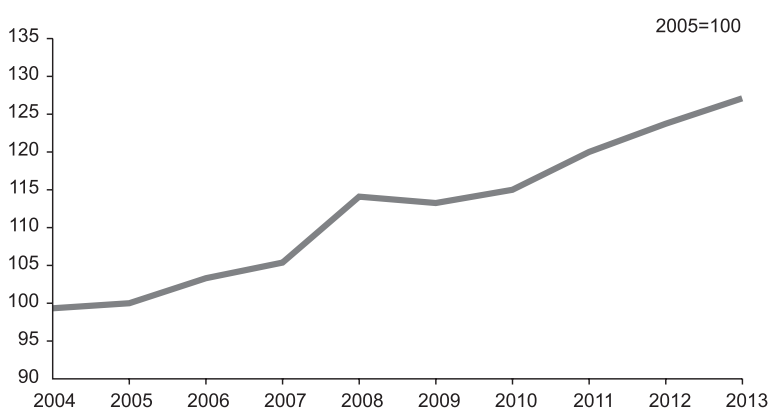

Figure 2 The Cost of Living Index in the Former Yugoslav Republic of Macedonia

Source: State Statistical Office, 2014, 32

Figure 3 shows the amount of the minimum salary in the European countries. The data have been grouped into three groups. The countries with the lowest salaries are in the first group, and the FYR Macedonia is one of them. The countries from the Western Balkans and Southeast Europe and Turkey belong to this group as well. Compared to the countries of the region, the citizens of the FYR Macedonia and Albania had the lowest minimum salary in January 2016, while the citizens of Slovenia received the highest.

The employed also have problems with poverty and they mainly have financial means to only satisfy their elementary needs for food and pay their bills. It is due to the fact that, beside the fact that living costs have permanently been increasing, the salaries paid out in the FYR Macedonia are the lowest average and the lowest minimum throughout the region. In May 2016, the average net salary per worker was 362 Euros (State Statistical Office - SSO, 2016). Since $1^{\text {st }}$ January 2016, the paid out net amount of the minimum salary has been 164 Euros, whereas the net salary in the amount of 146 Euros has been paid out in the sectors for the production of textile, clothes and leather products (Minimum Wage Legislation Act, 2012; 2015). In the FYR Macedonia, about $70 \%$ of the employed receive a net salary lower than the average salary. Only $7.5 \%$ of the employed receive a net salary in the amount exceeding 571 Euros.

Health protection is an essential segment for human security. The Ministry of Health is responsible for preparing the Health Policy in the FYR Macedonia and for monitoring the implementation of the same, for defining priorities in health protection and monitoring the functioning of the Health Protection System (Pavlovski, Antik, Friscik, Gelevska, Misev \& Kasapinov, 2014, 22). The Health Insurance Fund of the FYR Macedonia has the responsibility to collect and deliver financial means for obligatory health insurance. The two fundamental laws formulate the health system: Health Protection Law and Social Insurance Law. The Health Protection Law regulates citizens' rights to health protection, relationships and health insurance rights, the procedure of applying health protection as well as the system and organization of health protection. The Health Insurance Law regulates citizens' 
health insurance, rights to and obligations of the implementation of health insurance (Health Insurance Fund of Macedonia - HIFM, 2016).

According to the World Health Organization's data, the percentage put aside in the FYR Macedonia from the GDP for the purpose of covering healthcare costs is the lowest in comparison to the neighboring and the rest of the European countries. In the FYR Macedonia, $6.5 \%$ of the GDP is allocated for this purpose, whereas $10.4 \%$ is allocated in the Republic of Serbia, $7.8 \%$ in Croatia, 9.2\% in Slovenia, $9.6 \%$ in Bosnia and Herzegovina and $8.1 \%$ in Greece. France is the only European country with the highest allocated percentage of $11.5 \%$ of its GDP.
The European Health Consumer Index (EHCI) is a report prepared by the Health Consumer Powerhouse to evaluate the European Health Protection systems on the basis of the 48 indicators, according to which the ranking of the 35 countries included in the HCP research is defined. According to this index, the FYR Macedonia was ranked the $18^{\text {th }}$ (the eighteenth) out of the 35 countries in 2015. The improvement of the FYR Macedonia from the $28^{\text {th }}$ position in 2013 to the $18^{\text {th }}$ in 2015 is, first of all, the result of the access indicator (the time of waiting). Macedonia is the lowest-ranked country in respect of apoplexy decrease cases $\left(35^{\text {th }}\right)$, newborn baby mortality $\left(33^{\text {rd }}\right)$, high blood pressure $\left(22^{\text {nd }}\right)$, kidney

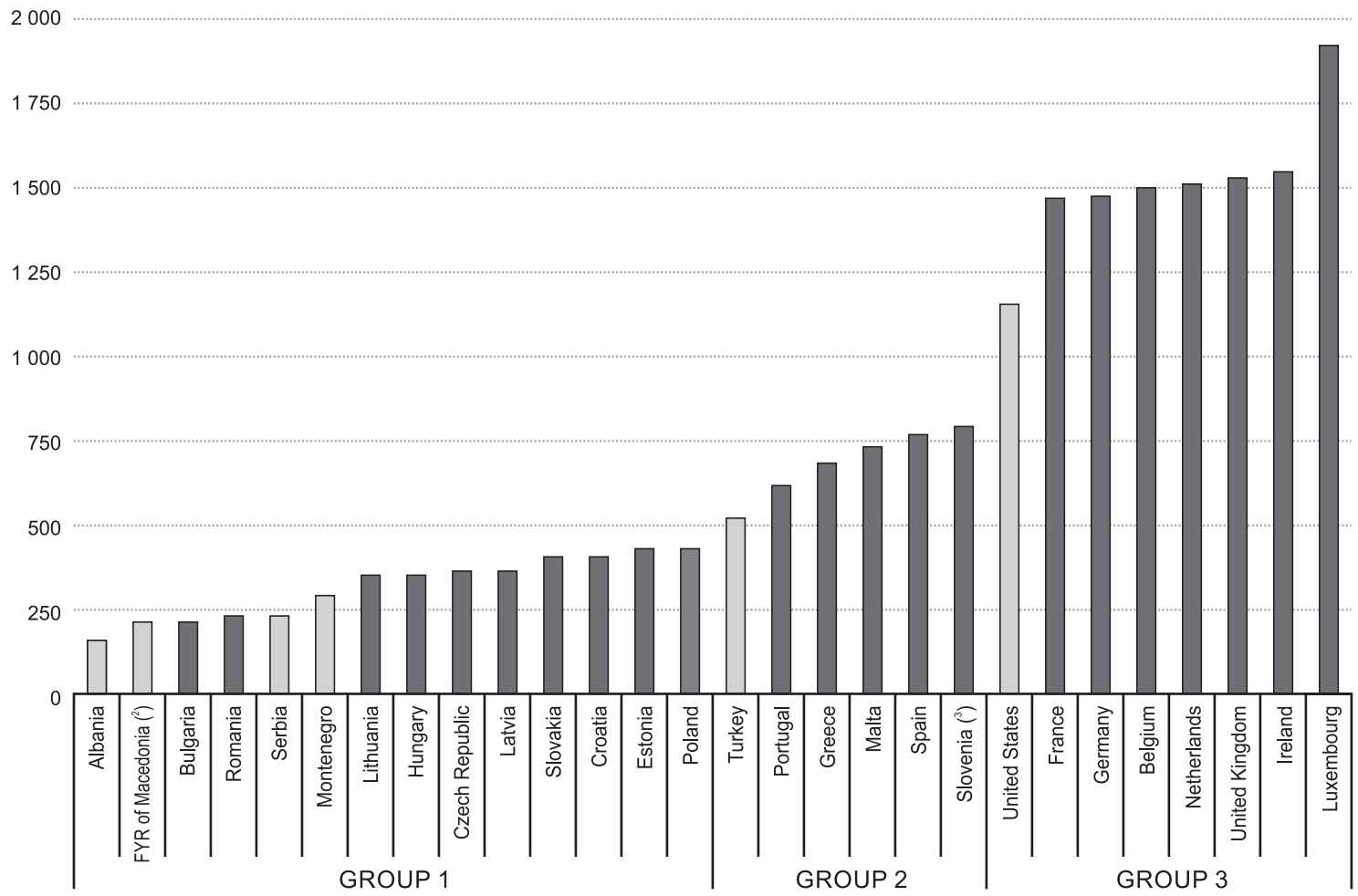

( ${ }^{1}$ Denmark, Italy, Cyprus, Austria, Finland and Sweden: no national minimum wa

(') January 2015 .

$\left({ }^{3}\right)$ July 2015.

Figure 3 The minimum salary, January 2016 (the monthly amount in Euros) 
transplantation $\left(29^{\text {th }}\right)$, dialysis treatments done at the time and in the place suitable to patients $\left(35^{\text {th }}\right)$, etc. These data lead us to conclude that, according to the European Health Consumer Index, the FYR Macedonia is a middle-ranked country, which is indicative of the fact that additional comprehensive reforms are necessary in financing, organizing and defining personnel affairs in order to improve the conditions and the quality of the Macedonian Health Services (Health Consumer Power House $\mathrm{HCPH}, 2016$ ).

\section{The Pension System of the FYR Macedonia - the State and the Problems}

Pension insurance is a part of social insurance. The Pension and Disability Insurance System and the disability insurance are implemented through the Pension and Disability Insurance Fund of the FYR Macedonia. The Pension and Disability Insurance Law regulates the rights to pension and disability insurance for the insured in the FYR Macedonia (Pension and Disability Insurance Fund of Macedonia - PDIFM, 2016).

The Pension and Disability Insurance System consists of:
- The First Pillar: Obligatory Pension and Disability Insurance on the basis of the generation solidarity;

- The Second Pillar: Obligatory and Capitally Financed Pension Insurance;

- The Third Pillar: Voluntarily and Capitally Financed Pension Insurance.

According to the PDIFM Report for 2015, the number of the insured for whom tax was paid account for 509.844 , i.e. $91.23 \%$ of the total number of the insured. The ratio of the insured that pay tax to pension users is 1.7 of an employed person for one user. (PDIFM, 2016, 8). If the trend of increasing the number of new age pension users in the period from 2008 to 2015 (Figure 4) is added to this ratio, as well as the population structure in the direction of an enlarged number of old persons in the total population, the situation is expected to be worsening. It will result in a further decrease in the ratio between the insured who pay tax and pension users (PDIFM, 2016). This change is, in fact, an indicator of the unsustainability of the existing pension system, which is operated on the basis of the age solidarity principle, in which those employed pay the present pensioners. The trend of new age pension is shown in Figure 4.

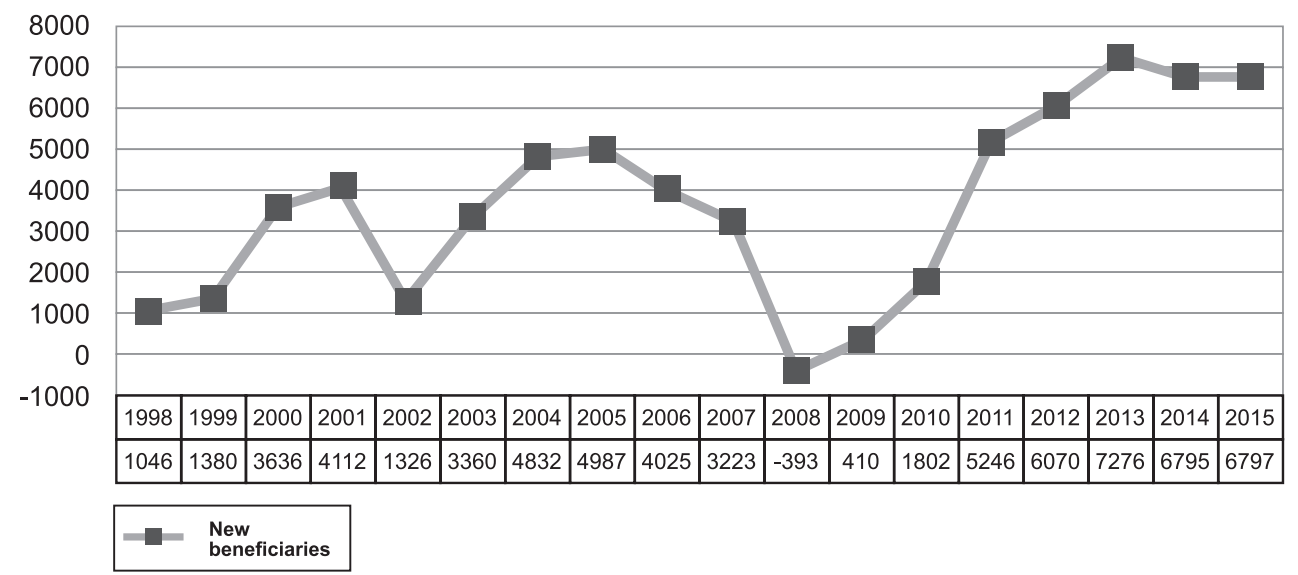

Figure 4 The influx of new age pension users in the period from 1998 to 2015 
The income structure is an important segment of the pension system, which is presented in Figure 5.

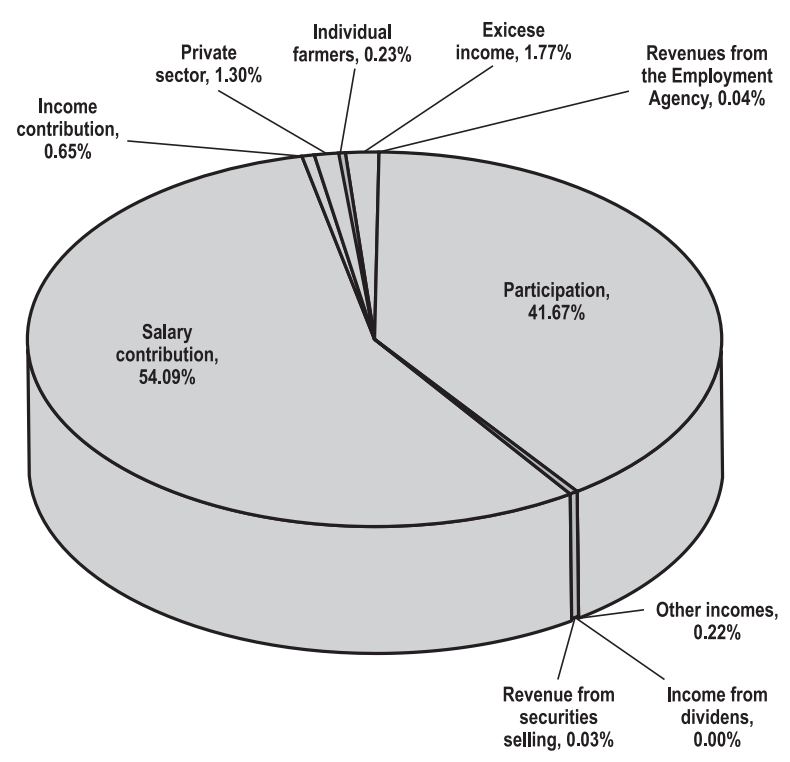

Figure 5 The income Structure

Source: PDIFM, 2016, 33

It could be noticed that, out of the total income, the participation of $41.7 \%$ is the one that follows. The data about the income in the period from 1996 to 2015 suggest a permanent rise in transfers from the Budget of the FYR Macedonia, which overloads the budget, on the one hand, and is not a solution to the PDIFM Fund problems, on the other. The fact that the Fund remains dependent of Budget Transfers (Figure 6) is highlighted. The data express the income sources: the greatest inflow of funds originates from the Employment Agency, which is followed by the income attributable to different categories and then succeeds the State Budget income. A permanent growth of the previously mentioned income is noticeable in the period taken into consideration. In 2015, the participation of expenditures for the pension and disability insurance in the GDP was $10.1 \%$.

In the World Bank Report (World Bank - WB, 2015, 119), the Macedonian Pension System is fiscally unsustainable in the mid-term and, in relation to the EU countries, the FYR Macedonia is a country with high pension costs. The contribution to the second private pension pillar is small to make a contribution to the compensation for decreased benefits of the first public pension pillar. According to a conservative scenario, pension deficiency will have been $10.5 \%$ of the GDP by 2030. An implicit

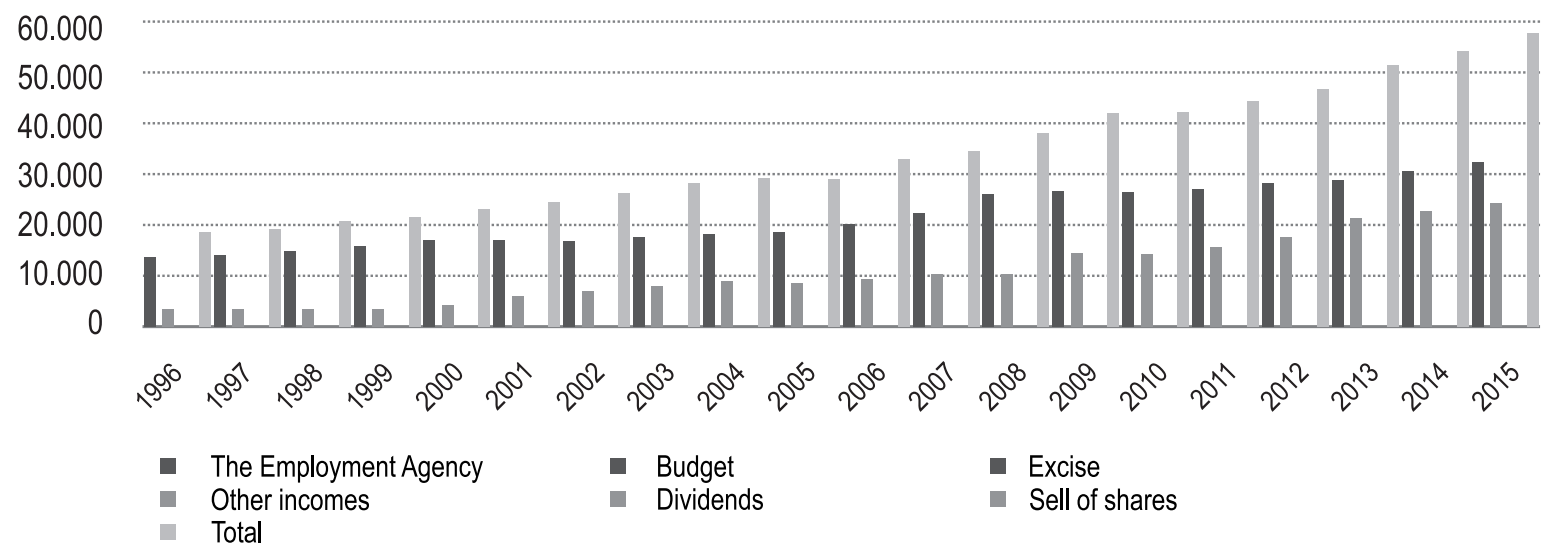

Figure 6 Income fluctuations per years (expressed in Denars - 1 Euro = 61.69 Macedonian denar) 
pension debt is projected to be over $400 \%$ of the GDP, which is much higher than the European standard. The obligations created by the nonfinanced pension diagram for future pensions to be paid are called an implicit pension debt. These future promises are demands from a future GDP of a country (van Kamiel, 2014, 9). A high implicit pension debt (IPD) could have serious consequences for the macroeconomic stability and it is a fiscal burden that must not be ignored, especially not so by the countries with high and medium income. The Government could reduce the IPD by increasing the retirement age (Palacios \& Kane, 1996, 38). A permanent increase in budget transfers towards the Fund of the PDIFM, a high implicit pension debt and the fiscal unsustainability of the Fund in the medium and long term point out a need for additional pension reforms. The recommendations for overcoming this problem are given in the following chapter.

\section{DISCUSSION OF THE RESULTS}

The low level of conditions provided for security and health at work points out the fact that the existing legal regulation is not fully applied. The absence of responsibility and care for companies' security and health in the FYR Macedonia is one of the reasons that pose a threat to the health and life of the employed. The unfavorable state in the field of security and health at work could be overcome by improving and efficiently applying the regulations in the field of security and health at work and through the promotion of the security and health standards at work. In this context, we would mention the conclusion drawn by the European Commission with respect to the improvement of the FYR Macedonia in this field. That is to say, it was alleged in the Report on the FYR Macedonia for 2015 related to security and health at work that change in the Security and Health at Work Law had to be made and two new books of rules passed, which was not done in consultation with the National Security and Health Council at work, but rather without any previous evaluation of their reconciliation with the European Union Law. The Report also emphasizes that the administrative capacity to provide an appropriate application of the regulations is not sufficient. So, additional reforms are necessary in order to comply with the European Union's Law in this field. Taking into consideration the stated conclusions, it is necessary to revise the regulations in this field by including appropriate institutions competent for the issues of security at work as well as experts from the EU countries, which will enable reconciliation between these regulations and those of the EU. The effective and efficient application of the laws is impossible without the existence of a certain capacity of the administrative services, including inspection supervision over the application of the laws. It implies taking measures and activities so as to increase the capacity in this filed. It is also necessary to find ways how to raise owners' and companies' management's awareness of the benefit the workers could be obtain if they were satisfied and healthy. Organizing workshops and training courses, as well as certain stimulation measures regarding business, could have an impact on the betterment of conditions in this field.

An efficient social policy, social protection and a decrease in unemployment are the fundamental components of decreasing poverty, providing a minimum living standard and a possibility for an active participation of all citizens in a society. The low employment rate, the low income of the employed and enlarged living costs point out that so far the social policy has not been solving a greater part of the social problems that the citizens of the FYR Macedonia are faced with. The European Commission (EC, 2015, 59) recommends that some measures and activities are necessary to take and carry out, respectively, in the field of the social policy and employment in order to raise the employment rate of the young and those who have been unemployed for a long time and provide 
appropriate institutions and financial resources in order to reduce poverty in the country. To reduce poverty and improve the living standard in the country, it is necessary to increase the minimum and the average net salary of the employed. The sustainability and competition of the domestic and foreign companies should be the Government's priority. This could be achieved by converting a part of the funds from the state budget, from unproductive to capital investments, which would allow a rise in the economic growth of the country, the creation of new jobs and unemployment reduction.

The EU and other countries' experiences in the world indicate the existence of a long-term process of the pension system adaption depending on the changes of the influential factors on their functioning. Modern economic research studies suggested the using of a gradual transfer from the pension system operated on the basis of the generation solidarity principle to and towards the modern private pillars, i.e. relying on the second and the third pension pillars instead of relying on the first public pension pillar. This transfer could be facilitated by providing a simple entry in the private pension plans under such circumstances in which the entry is not conditioned by funding and employment. Future pensioners would have to decide whether they are going to choose the socalled Individual Pension Plans (e.g. the Individual Retirement Account, in the USA, or the Individual Savings Account, in GB) or the so-called Profession or Training Pension Schedules, in which the funds paid in such an account are managed through Trade Unions, Unions, Clusters or Trade Organizations. Some additional activities should also be carried out for the purpose of the development of life insurance as an alternative kind of savings in order to provide additional funds to supplement pension income. With the latest changes in the Labor Relations Act in the FYR Macedonia, the retirement age limits are 64 years of age for men and 62 years of age for women, with the opportunity for the employed to decide whether they will have their employment agreement prolonged for yet another three years or not. So, in contrast to other countries, according to our legal changes, the extension of the employment agreement is not a legal obligation, but rather a choice made by an employee. In order to secure the sustainability of the Macedonian Pension System, it is necessary to make changes in relation to an increase in the retirement age limit following the example of the rest of the European countries. This measure could be supplemented with the application of appropriate stimulations in a sort of a monthly pension raise for those who will retire later on or penalties for each month of early retirement. By prolonging the work age, as well as by eliminating a decision on freeing foreign investors from paying tax, pressure on the PDIF of the FYR Macedonia and pressure on the Budget of the FYR Macedonia will both be reduced (Gruevski \& Gaber, 2014).

An efficient health system is essential for achieving general welfare in every country. As directions given with respect to the improvement of the conditions in the Macedonian Health System, the recommendations of the World Bank will be mentioned, according to which, in order to improve their health systems, countries should focus on:

- the improvement of health results;

- better financing, in order to provide sustainable health; and

- the strengthening of the institutional positioning.

The unsatisfactory conditions in Macedonian health point out a need for the urgent diagnosing of the reasons for such bad results in the health system in order to overcome the existing problems. That is why a detailed analysis of the conditions in the health system is necessary, together with their comparing with the regulations and positive practice in European countries.

Only with this kind of a comprehensive approach could reconciliation be achieved in compliance 
with citizens' real needs and conditions for general human security in the FYR Macedonia created because they are interconnected with each other in a domino effect. It means that any disruption of the conditions in the analyzed segments leads to the deterioration of general human security.

\section{CONCLUSION}

Human security is an important concept referring to the citizens of a society. The concept contains a few key elements referring to the social and political environment, economic development, social and health protection and workplace security, which has a direct impact on the quality of life in a society.

The analysis that has been carried out regarding the conditions in the above-mentioned segments of the public sector in the FYR Macedonia has indicated the fact that the human security concept is very little talked about. Simultaneously, there is no devotion and no political will on institutions' part to implement the European principles of human security that would be used as a guide for a clear formulation of the human security concept in accordance with the Macedonian conditions and the needs of the citizens of the FYR Macedonia.

The FYR Macedonia has been making economic, political, social and other efforts in order to fulfil the obligations for its membership to the EU. In this sense, it is necessary that reforms should be implemented in the Pension System, the Health System and the Social Protection System and that the conditions for the protection and security of workers at their workplaces should be improved, too. From the analysis of the conditions in the focused segments of the public sector, it could be concluded that the reforms which have been implemented have not given the desired effects. The offered measures and the suggested activities with respect to the application of the human security concept in this paper offer opportunities to highlight the issues referring to this particular concept. The further ignoring and postponement of a debate over changes in the conditions in the public sector from the aspect of human security could be surpassed by the contribution that could be made by research papers of this kind so that administration could gain know how in order to solve the open issues referring to the clear understanding of human security.

Writing about and debating over the surpassing of the problems in the public sector, however, require transparency and cooperation with public institutions, which, in this case, is missing. Actually, this is the limiting factor of our research.

Our research has confirmed the hypothesis that it is essential to implement profound reforms in the Macedonian Health and Social Sectors, the Pension System and in the field of human security at work in order to achieve a higher level of general human security in the FYR Macedonia.

The research results presented in this work are a motivation factor for conducting future research studies in this field. Our future research studies will give an opportunity to close up numerous open questions, such as: Which strategy should be applied in the FYR Macedonia in order to achieve a general level of human security? Which way should the chosen strategy be used in? Which effects are going to be achieved with the application of the human security concept? Our future research will help to have this concept successfully implemented in the FYR Macedonia.

\section{REFERENCES}

Alli, B. (2008). Fundamentals principles of occupational health and safety. International Labour Office. Geneva.

Devon, A. (2014). Human security concept in political and academic circles. Tehnički glasnik, 8(3), 309-313. 
EUROFOUND. (2012). Fifth European Working Conditions Survey. Publications Office of the European Union. Luxembourg.

European Commission. (2015). Report on the Republic of Macedonia for 2015. Brussel.

Eurostat Statistics. (2016a). Retrieved from http://ec.europa. eu/eurostat/statistics-explained/index.php/File:At-riskof_poverty_or_social_exclusion_rate,_2013_and_2014. png

Eurostat Statistics. (2016b). Retrieved from http:// ec.europa.eu/eurostat/statistics-explained/index.php/ File:Minimum_wages,_January_2016_(\%C2\%B9)_(EUR_ per_month)_YB16-II.png

Grozdanovski, A. et all. (2015). Strategies for improving the safety and health at work Republic of Macedonia through the active participation of civil society organizations, Macedonian association for protection at work. Skopje. Retrieved from http://www.cso-osh.org/images/dok/STRATEGIJA_BZR. pdf

Gruevski, I., \& Gaber, S. (2014, September 11-13). Pension reform globally (general trends and directions). Paper presented at the International scientific conference Social change in the global world, Stip, Macedonia. Retrieved from http://eprints.ugd.edu.mk/11561/

Health Consumer Power House. (2016). Retrieved from http://indicators.healthpowerhouse.com/ehci2015indicators

Mayor, F. (1999). Letters to future generation. France: UNESCO. Retrieved from http://unesdoc.unesco.org/ images/0011/001185/118573E.pdf

Ministry of Labor and Social Policy (2010). National Program for Development of Social Protection: 2011-2020. Skopje.

Ogata, S. (1998). Inclusion or exclusion: Social development challenges for Asia and Europe. Statement of Mrs. S. Ogata, United Nations High Commissioner for Refugees at the Asian Development Bank Seminar. Retrieved from http://www.unhcr.org/admin/hcspeeches/3ae68fcd54/ statement-mrs-sadako-ogata-united-nations-highcommissioner-refugees-asian.html

Palacios, R., \& Kane, C. (1996, June). The Implicit Pension Debt. Finance \& Development, 36-38. Retrieved from https://www.imf.org/external/pubs/ft/fandd/1996/06/ pdf/kane.pdf
Pavlovski, B., Antik, D., Friscik, J., Gelevska M., Misev, S., \& Kasapinov, B., (2014). We are all human: Health care for all people regardless of their ethnicity. Health status, health care and the right to health among Roma people in the Republic of Macedonia. Foundation Open Society. Skopje, The Former Yugoslav Republic of Macedonia.

Pejkovski, J., \& Majovski, I. (n.d.) Reform process and challenges of social policy in Macedonia. Framing a new social policy: actors, dimensions and reforms Friedrich Ebert Foundation, Office of Skopje, The Former Yugoslav Republic of Macedonia.

Pension and Disability Insurance Fund of Macedonia. (2016). Retrieved from http://www.piom.com.mk

PWC. (2014). Social security systems around the globe. Retrieved from https://www.pwc.com/socialsecurity

Social Protection Act, Official Gazette of the Republic of Macedonia. (2009). Retrieved from http://mtsp.gov.mk/ WBStorage/Files/zakon_so_zastita_osnoven.pdf

Sokov, I. (2012). Human security as the universal value. The Journal of Human Security. 8(1), 68-79.

Spicker, P. (2000). The Welfare State: a general theory. London, UK: Sage.

Stanarević, S. (2014). State/national security and human security. Small Guide through the Human Security. Novi Pazar, The Republic of Serbia: Cultural center DamaD.

State Labor Inspectorate. (2016). Retrieved from http:/ www.dit.gov.mk/godisniIzvestai.php

State Statistical Office. (2014). Macedonia in numbers.

State Statistical Office. (2016). Survey on Income and Living Conditions - 2015.

StateStatisticalOffice.(2016).Wages:Newsrelease.Retrieved from http://www.stat.gov.mk/pdf/2016/4.1.16.57.pdf_

Thakur, R. (1997). From National to Human Security, In S. Harris, \& A. Mack (Eds.), Asia-Pacific Security: The Economics, Politics Nexus (pp. 52-80). Sydney, Australia: Allen \& Unwin.

UNESCO. (1999). Letters to Future Generations. United Nations Educational, Scientific and Cultural Organization. Paris, France.

United Nations Development Programme (UNDP). (1994). Human Development Report. New York, NY: Oxford University Press. 
van Kamiel, L. (2014). Implicit Pension Debt and Credit Rating: International comparison of implicit pension debts with particular focus on the Netherlands. (Master thesis, Tilburg School of Economics and Management), Retrieved from http://arno.uvt.nl/show.cgi?fid=136220.
Veselinovic, P. (2014). The reforms of the public sector as the key determinant of the transition economy of the Republic of Serbia. Economic Horizons, 16(2), 137-155. doi: 10.5937/ekonhor1402141V.

Received on $23^{\text {rd }}$ March 2017, after one revision, accepted for publication on $24^{\text {th }}$ April 2017.

Published online on $28^{\text {th }}$ April 2017.

Meri Boshkoska is an Associate Professor at the Faculty of Economics in Prilep, St. Kliment Ohridski, University of Bitola, the Former Yugosalv Republic of Macedonia. She received her $\mathrm{PhD}$ in Economics, at the Institute of Economics in Skopje, Ss. Cyril and Methodius, University of Skopje, the Former Yugosalv Republic of Macedonia. Her scientific research interest is focused on international finance and bussines, and financial management. 


\title{
SOCIAL AND ECONOMIC ASPECTS OF THE HUMAN SECURITY CONCEPT
}

\author{
Meri Boshkoska* \\ Faculty of Economics, Prilep, University St. Kliment Ohridski, Bitola, \\ The Former Yugoslav Republic of Macedonia
}

The objective of this work is to analyze the real state in the field of the Macedonian Health and Social Policy, the pension system and human security at work. This type of analysis will make it possible to deduce certain conclusions and recommendations about accomplishing a higher level of general human security in the Former Yugoslav Republic of Macedonia. The results of this study enable us to conclude that, in the Former Yugoslav Republic of Macedonia, living expenses have been permanently increased, the unemployment rate is high and the average minimum wages paid in the region are the lowest, which all contributes to profound poverty in the country. It is also necessary to revise the laws and regulations in the field of workers' health and security, make urgent changes in order to ensure the sustainability of the pension system and also start the reforms that will provide a sustainable and efficient health care system.

Keywords: pension system, social security, poverty rate, health care system

JEL Classification: I31, I32, H55

\section{INTRODUCTION}

In order to make our contribution to a better understanding of the human security concept and its successful introduction and practical use in the Former Yugoslav Republic of Macedonia (FYR Macedonia), the limelight of this work is to study the real state of social living as well as the legislation

* Correspondence to: M. Boshkoska, Faculty of Economics, Prilep, University St. Kliment Ohridski, Bitola, Marksova bb, 7500 Prilep, The Former Yugoslav Republic of Macedonia; e-mail:meribb@yahoo.com and the institutions of the FYR Macedonia whose subjects of work are: health and social insurance, pension insurance and human security at work. The analysis of the achieved results will help to offer recommendations for the improvement of the conditions in the previously mentioned fields, which are quite important if we want to reach general human security.

Having in mind the objective of the study, the main hypotheses of our research are as follows: It is essential to implement profound reforms in the Macedonian Health and Social Sectors, the Pension 
System and in the field of human security at work in order to achieve a higher level of general human security in the FYR Macedonia.

The research methodology consists of a combination of different methodological aspects based on:

- a content analysis of various institutional documents and research papers dealing with human security, a pension system analysis, social and health safety and health and safety at work;

- using administrative databases and numerical data for the purpose of explaining the research issues;

- a deduction approach will be applied through the content analysis.

The rest of the paper is structured as follows: in the second section, a literature review is presented, focusing on understanding the meaning of the human security concept. In the third section, the results of the current situation and the legislative framework in the areas of security and health at work, social and health protection and the state and the problems in the pension system of the FYR Macedonia are presented. In the fourth section, the research results are subjected to discussion. The last section of the paper presents the conclusion of the study.

\section{LITERATURE REVIEW}

There are various definitions of the human security concept, depending on the starting point of their explanation. S. Stanarević $(2014,10)$ emphasizes the fact that, first of all, a distinction between national and human security should be made. Human security is the concept that refers to people and the community, not to countries and their territories. This author points out the explanation of the United Nations Organization (UNDP) from 1994, according to which human security is a concept oriented towards humans, the basic element of which is our becoming free from fear and poverty. According to R. Thakur (1997, 5354), social and political empowerment, economic growth and improved access to resources are among the factors that can influence the improvement of human security. K. Anan (UNESCO, 1999, 15) points out that human security could no longer be explained by military terms. In itself, it includes economic development, social justice, environment protection, democratization, disarmament, respecting human rights and the rule of law. According to $\mathrm{S}$. Ogata (1998), human security consists of several key elements, namely:

- an opportunity for all citizens to live in peace and securely within the state borders;

- people should enjoy their rights and obligations (human, political, social, economic and cultural rights) with no discrimination;

- social inclusion or the same approach to political, social and economic politics;

- rule of law and an independent legal system.

In the 1994 Human Development Report (UNDP, 1994, 22-23), the UNDP points out the two main aspects of human security:

- security against famine, diseases and repression, and

- protection from sudden, harmful disorders in a human's everyday life.

The said report emphasizes the fact that human security could be analyzed from the seven categories (UNDP, 1994, 24-25): economic security, health security, food security, environmental security, personal security, political security and community security.

A. Devon (2014) sums up that human security concept also includes challenges people face on a daily basis, such as job security, education opportunities, social and cultural freedoms.

P. Veselinovic (2014) states that in order to improve the quality of life in the Republic of Serbia, it is necessary that structural reforms in the pension, social security and healthcare systems be undertaken. 
Various definitions of the human security concept indicate the necessity of having an integral perception of human security in order to prevent it from disseminating in different directions (Sokov, 2012).

Opinions similar to these suggest that the human security concept includes the important elements of social living that allow a high level of citizens' quality and secure life.

\section{AN ANALYSIS OF THE STATE OF AND THE LEGAL REGULATION IN THE PENSION, SOCIAL AND HEALTH FIELDS, AS WELL AS THE WORK RELATIONSHIPS}

\section{Security and Health at Work}

Security and health at work is an interdisciplinary concept dealing with prevention from professional risks connected to every work activity. The main objective of this concept is to induce and maintain the highest level of security and health at work, that is to say providing conditions to prevent and protect workers from occupational risks (Alli, 2008, 20).

In the FYR Macedonia, workers' security and health are regulated by the following laws (Grozdanovski et all, 2015, 7): Security and Health at Work Law; Working Relationships Law; Health Protection Law; Pension and Disablement Insurance Law; Law on Protection from Disturbance at Work; Labor Evidence Law; Health Insurance Law; Labor Inspection Law.

From the aspect of regulating Security and Health at Work Conditions, the existence of the abovementioned law, as well as numerous subordinate legislation acts, a picture has been created in which the security and health of employers in the FYR Macedonia has been provided. However, in the FYR Macedonia, there is an insufficient provision of workers' security and health of at work (Grozdanovski et al, 2015, 8-9). It is confirmed by the data in the annual reports of the State Inspectorate, according to which a remarkable and continuous increase in body injuries is noticeable in 2010, 2011 and 2012. In 2010, 625 injuries at work were recorded; in 2011, their number was 786, whereas in 2012, the total number of the registered injuries at work was amounted to 1446 (State Labor Inspectorate - SLI, 2016). These data confirm the ranking of the countries in this field, done by the European Foundation for the Improvement of the Life and Work Conditions (EUROFOUND).

In the EUROFOUND research, the FYR Macedonia is the country with the highest level of exposure to physical risks. This research included 34 countries and 44,000 workers in the period from January to June 2010. The research is conducted every five years and the results are estimated on the basis of a representative sample of European workers, not on the basis of the whole of the population. The data show that a great number of injuries which often end with fatal consequences upon a human life and inappropriate conditions and carelessness with respect to workers' health cause long-term social problems that affect workers' ability. This conclusion leads to a need for measures and activities of the institutions responsible for doing so, by which the existing risks at work will be decreased. This will provide higher security for the employed and better working conditions.

In the recommendations part, the measures and activities that could contribute to an improvement of the state in the field of security and health at work in our country will be pointed out.

\section{Social and Health Protection}

The social and health protection of citizens have been an important segment of the rule of the Government. The social policy term has been used in order to mark governmental policies for the realization of welfare and social protection, as well as the ways in which welfare in a society is achieved (Spicker, 2000, 111-112).

"Social safety refers to the services provided by the social state in many kinds and forms designed for the protection of citizens" (Pejkovski \& Majovski, n.d, 113). 
Social protection is a system of measures, activities and policies for preventing and overcoming the basic social risks citizens are exposed to during their lives, for decreasing poverty and social exclusion, and for strengthening the citizen's capacity for his/her own protection (Law on Social Protection, Article 2, 2009, 1).

The Ministry of Labor and Social Politics is the central institution that creates policies, strategic planning, administration and monitoring of the realization and application of laws and regulations in the field of social protection in the FYR Macedonia. The Government of the FYR Macedonia hands down the National Program for Social Protection Development, which defines the objectives, priorities and directions of the development of social protection for citizens (MLSP, 2010, 8).

The Social Protection System in the FYR Macedonia is the system of measures, activities and policies for the prevention of and exceeding the basic social risks citizens are faced with during their lives. The basic social risks include: health risks, the risk of aging and becoming old, the single parent risk, the unemployment risk, the poverty risk and other kinds of social exclusions (PWC, 2014, 211).

The Social Security Law settles the system and organization of social protection, social protection rights, financing and the procedure of the realization of social protection rights ("Social Protection Law", Article 2, 2009, 1).

Among other laws falling within the field of social protection in the FYR Macedonia, there are the following ones as well: The Family Law; The Asylum and Temporary Protection Law; The Disability Organizations Law and other laws.

The existence of an appropriate legal regulation and reform processes in the field of social protection is not sufficient to improve the social state of almost one-half of citizens in our country. This has been confirmed by numerous inland and foreign studies as well as by the State Statistical Office (SSO) of the FYR Macedonia. The Income and Living Conditions Poll is an annual research study carried out by the State Statistical Office and a source of data on poverty and social exclusion. According to the data about income and living conditions obtained from this poll, the State Statistical Office estimates the socalled Laeken indicator of the poverty rate. In 2015, the rate of poverty-stricken individuals in the FYR Macedonia was $21.5 \%$ of the total population, i.e. 457,000 individuals (State Statistical Office, 2016, 35). This means that these individuals can be categorized into at least one of the following situations:

- a poverty risk, after social transfers;

- socially and materially deprived individuals;

- individuals who live in households with very low work intensity.

The fact that the greatest number of citizens who live in the FYR Macedonia are faced with poverty is shown in Figure 1, where a comparison between the poverty rate, i.e. social exclusion in the FYR Macedonia, on the one hand, and that of the European Union (EU), on the other, is presented. According to the diagram data, in 2014, the FYR Macedonia was at the top of the list of the citizens who have faced poverty.

Living expenses have a great impact on an increase in the poverty rate. According to the COICOP Classification, the Cost of Living Index was annually increased by $2.8 \%$ in 2013 . Table 1 accounts for the costs of living index of some important groups.

According to the data demonstrated in this chart, an increase in prices is noticed in the groups of: health, education, alcoholic drinks, clothes and footwear, soft drinks, other goods and services, furniture, household goods and maintenance of the household goods and housekeeping, water, electricity, gas and 


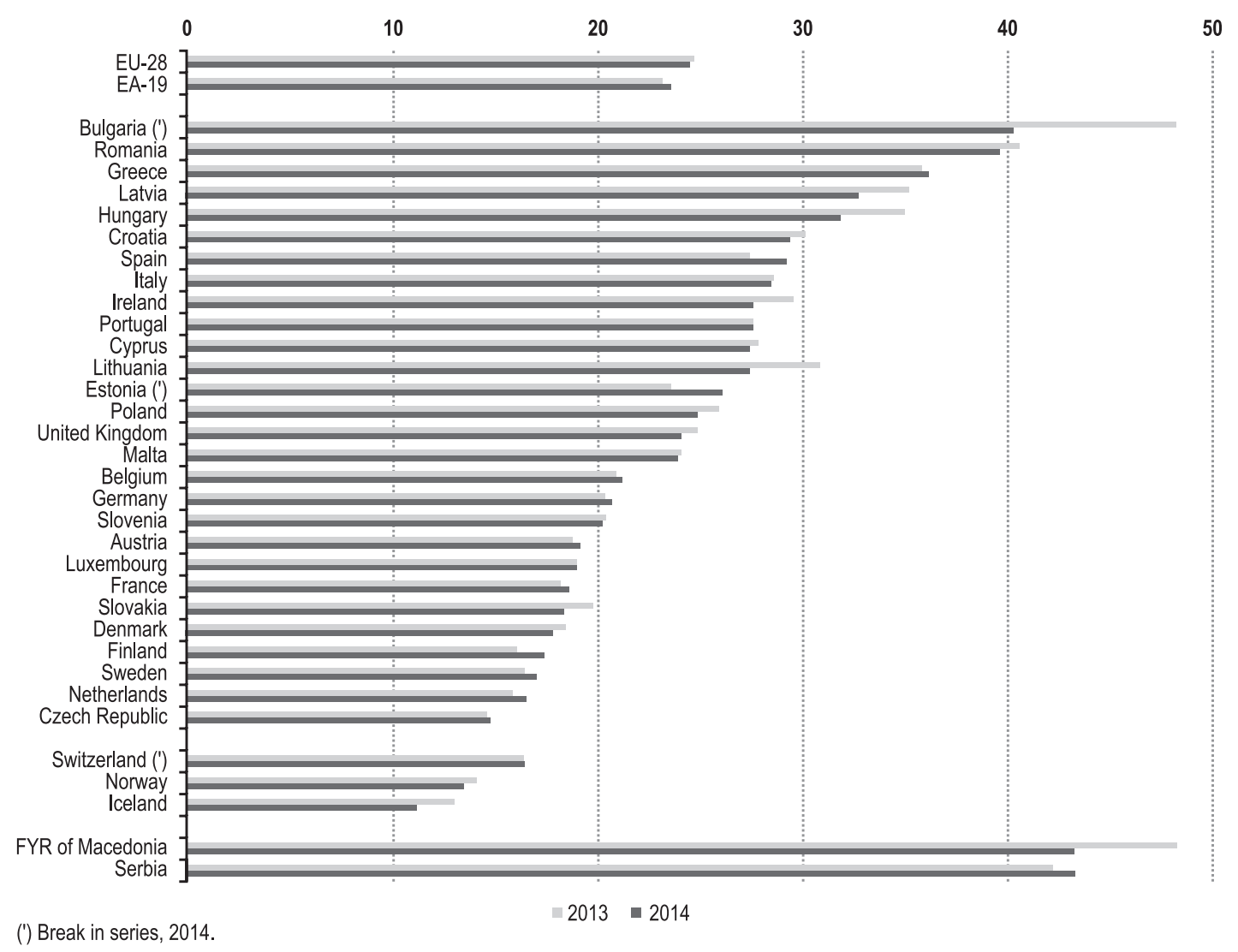

Figure 1 Poverty or Social Exclusion Rate, 2013 and 2014

Source: Eurostat statistics, 2016a

other fuels. A decrease in prices is noticed in the Communication and Transport Sector, Recreation and Culture (State Statistical Office, 2014, 31).

The Cost of Living Index in the FYR Macedonia is presented in Figure 2. It could be noticed that, in the period from 2004 to 2013, the Cost of Living Index permanently increased, which had an impact on the poverty rate in that the same made it increase.

The employed also have problems with poverty and they mainly have financial means to only satisfy their elementary needs for food and pay their bills. It is due to the fact that, beside the fact that living costs have permanently been increasing, the salaries paid out in the FYR Macedonia are the lowest average and the lowest minimum throughout the region. In May 2016, the average net salary per worker was 362 Euros (State Statistical Office - SSO, 2016). Since $1^{\text {st }}$ January 2016, the paid out net amount of the minimum salary has been 164 Euros, whereas the net salary in the amount of 146 Euros has been paid out in the sectors for the production of textile, clothes and leather products (Minimum Wage Legislation Act, 2012; 2015). In the FYR Macedonia, about $70 \%$ of the employed receive a net salary lower than the average salary. Only 7.5\% of the employed receive a net salary in the amount exceeding 571 Euros. 
Table 1 The Cost of Living Index Classification according to $\mathrm{COICOP}$

\begin{tabular}{|c|c|c|c|}
\hline & 2011 & 2012 & 2013 \\
\hline Total & 103.9 & 103.3 & 102.8 \\
\hline $\begin{array}{l}\text { Food and non-alcoholic } \\
\text { beverages }\end{array}$ & 106.2 & 102.3 & 103.4 \\
\hline $\begin{array}{l}\text { Alcoholic beverages, } \\
\text { tobacco }\end{array}$ & 101.0 & 100.2 & 104.0 \\
\hline Clothes and shoes & 101.4 & 105.4 & 107.0 \\
\hline $\begin{array}{l}\text { Housing, water, } \\
\text { electricity, gas and other } \\
\text { fuels }\end{array}$ & 105.0 & 109.2 & 101.0 \\
\hline $\begin{array}{l}\text { Furnishings, household } \\
\text { equipment, maintenance of } \\
\text { the house }\end{array}$ & 100.9 & 100.6 & 101.9 \\
\hline Health & 103.8 & 103.0 & 108.4 \\
\hline Transport & $105 \cdot 3$ & 106.3 & 99.3 \\
\hline $\begin{array}{l}\text { Communication (PTT } \\
\text { services) }\end{array}$ & 98.3 & 95.8 & 99.0 \\
\hline Recreation and culture & 99.1 & 98.6 & 97.9 \\
\hline Education & 94.3 & 103.6 & 106.6 \\
\hline Restorants and hotels & 101.9 & 103.1 & 104.1 \\
\hline Other goods and services & 102.4 & 103.4 & 102.7 \\
\hline
\end{tabular}

Source: State Statistical Office, 2014, 31

Figure 3 shows the amount of the minimum salary in the European countries. The data have been grouped into three groups. The countries with the lowest salaries are in the first group, and the FYR Macedonia is one of them. The countries from the Western Balkans and Southeast Europe and Turkey belong to this group as well. Compared to the countries of the region, the citizens of the FYR Macedonia and Albania had the lowest minimum salary in January 2016, while the citizens of Slovenia received the highest.

Health protection is an essential segment for human security. The Ministry of Health is responsible for preparing the Health Policy in the FYR Macedonia and for monitoring the implementation of the same, for defining priorities in health protection and monitoring the functioning of the Health Protection System (Pavlovski, Antik, Friscik, Gelevska, Misev \& Kasapinov, 2014, 22). The Health Insurance Fund of the FYR Macedonia has the responsibility to collect

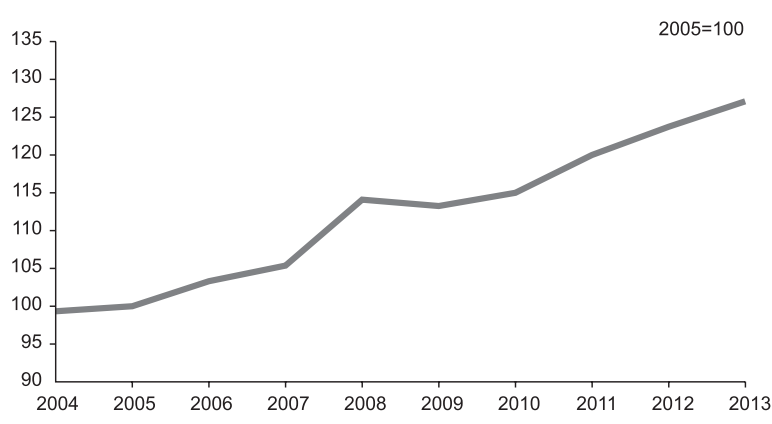

Figure 2 The Cost of Living Index in the Former Yugoslav Republic of Macedonia

Source: State Statistical Office, 2014, 32

and deliver financial means for obligatory health insurance. The two fundamental laws formulate the health system: Health Protection Law and Social Insurance Law. The Health Protection Law regulates citizens' rights to health protection, relationships and health insurance rights, the procedure of applying health protection as well as the system and organization of health protection. The Health Insurance Law regulates citizens' health insurance, rights to and obligations of the implementation of health insurance (Health Insurance Fund of Macedonia - HIFM, 2016).

According to the World Health Organization's data, the percentage put aside in the FYR Macedonia from the GDP for the purpose of covering healthcare costs is the lowest in comparison to the neighboring and the rest of the European countries. In the FYR Macedonia, $6.5 \%$ of the GDP is allocated for this purpose, whereas $10.4 \%$ is allocated in the Republic of Serbia, $7.8 \%$ in Croatia, $9.2 \%$ in Slovenia, $9.6 \%$ in Bosnia and Herzegovina and $8.1 \%$ in Greece. France is the only European country with the highest allocated percentage of $11.5 \%$ of its GDP.

The European Health Consumer Index (EHCI) is a report prepared by the Health Consumer Powerhouse to evaluate the European Health Protection systems on the basis of the 48 indicators, according to which the ranking of the 35 countries included in the HCP research is defined. According to this index, the 
FYR Macedonia was ranked the $18^{\text {th }}$ (the eighteenth) out of the 35 countries in 2015. The improvement of the FYR Macedonia from the $28^{\text {th }}$ position in 2013 to the $18^{\text {th }}$ in 2015 is, first of all, the result of the access indicator (the time of waiting). Macedonia is the lowest-ranked country in respect of apoplexy decrease cases $\left(35^{\text {th }}\right)$, newborn baby mortality $\left(33^{\text {rd }}\right)$, high blood pressure $\left(22^{\text {nd }}\right)$, kidney transplantation $\left(29^{\text {th }}\right)$, dialysis treatments done at the time and in the place suitable to patients $\left(35^{\text {th }}\right)$, etc. These data lead us to conclude that, according to the European Health Consumer Index, the FYR Macedonia is a middleranked country, which is indicative of the fact that additional comprehensive reforms are necessary in financing, organizing and defining personnel affairs in order to improve the conditions and the quality of the Macedonian Health Services (Health Consumer Power House - HCPH, 2016).

\section{The Pension System of the FYR Macedonia - the State and the Problems}

Pension insurance is a part of social insurance. The Pension and Disability Insurance System and the disability insurance are implemented through the Pension and Disability Insurance Fund of the FYR Macedonia. The Pension and Disability Insurance Law regulates the rights to pension and disability insurance for the insured in the FYR Macedonia (Pension and Disability Insurance Fund of Macedonia - PDIFM, 2016).

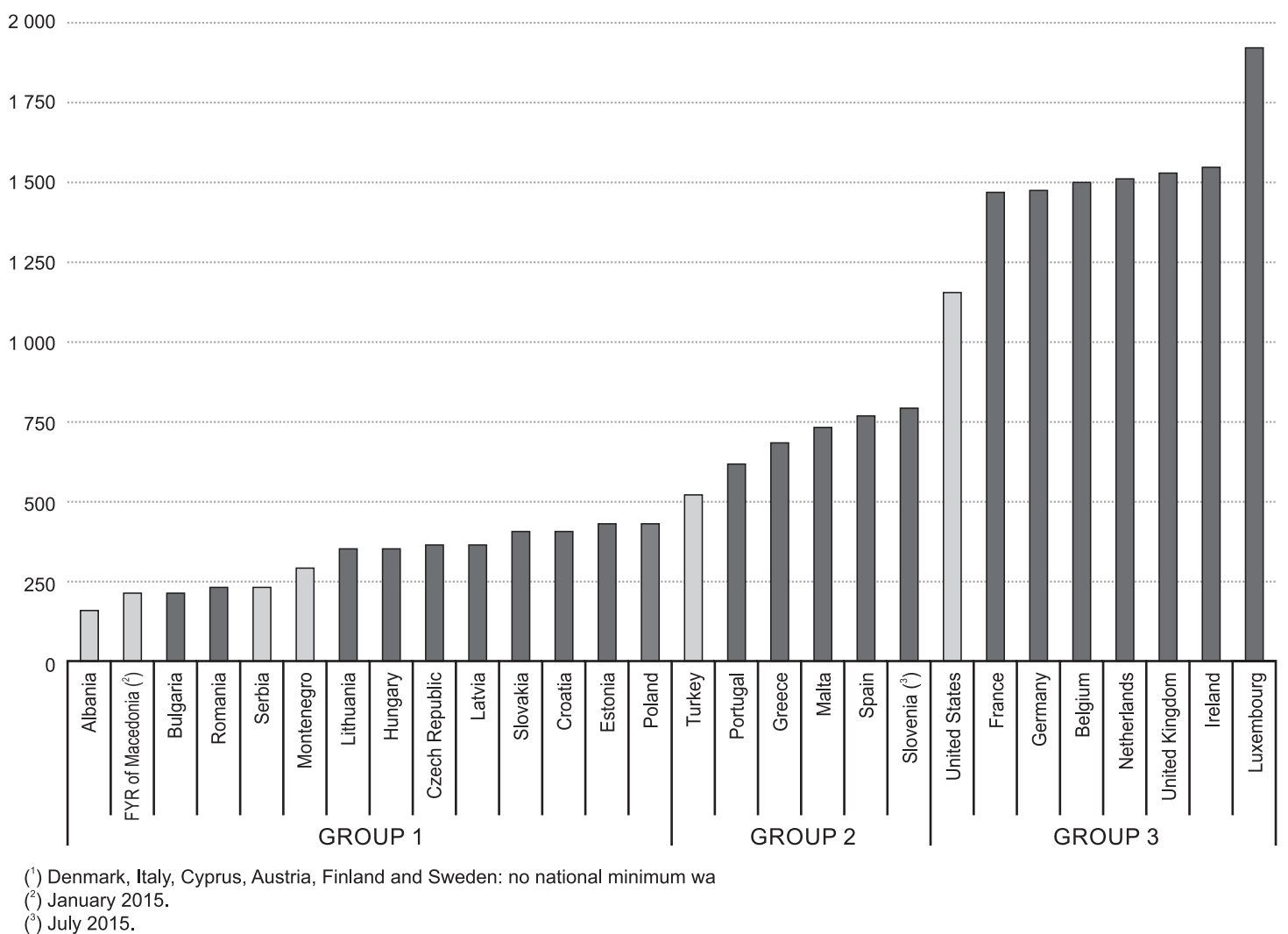

Figure 3 The minimum salary, January 2016 (the monthly amount in Euros) 
The Pension and Disability Insurance System consists of:

- The First Pillar: Obligatory Pension and Disability Insurance on the basis of the generation solidarity;

- The Second Pillar: Obligatory and Capitally Financed Pension Insurance;

- The Third Pillar: Voluntarily and Capitally Financed Pension Insurance.

According to the PDIFM Report for 2015, the number of the insured for whom tax was paid account for 509.844 , i.e. $91.23 \%$ of the total number of the insured. The ratio of the insured that pay tax to pension users is 1.7 of an employed person for one user. (PDIFM, 2016, 8). If the trend of increasing the number of new age pension users in the period from 2008 to 2015 (Figure 4) is added to this ratio, as well as the population structure in the direction of an enlarged number of old persons in the total population, the situation is expected to be worsening. It will result in a further decrease in the ratio between the insured who pay tax and pension users (PDIFM, 2016). This change is, in fact, an indicator of the unsustainability of the existing pension system, which is operated on the basis of the age solidarity principle, in which those employed pay the present pensioners. The trend of new age pension is shown in Figure 4.
The income structure is an important segment of the pension system, which is presented in Figure 5.

It could be noticed that, out of the total income, the participation of $41.7 \%$ is the one that follows. The data about the income in the period from 1996 to 2015 suggest a permanent rise in transfers from the Budget of the FYR Macedonia, which overloads the budget, on the one hand, and is not a solution to the PDIFM Fund problems, on the other. The fact that the Fund remains dependent of Budget Transfers (Figure 6) is highlighted. The data express the income sources: the greatest inflow of funds originates from the Employment Agency, which is followed by the income attributable to different categories and then succeeds the State Budget income. A permanent growth of the previously mentioned income is noticeable in the period taken into consideration. In 2015, the participation of expenditures for the pension and disability insurance in the GDP was $10.1 \%$.

In the World Bank Report (World Bank - WB, 2015, 119), the Macedonian Pension System is fiscally unsustainable in the mid-term and, in relation to the EU countries, the FYR Macedonia is a country with high pension costs. The contribution to the second private pension pillar is small to make a contribution to the compensation for decreased benefits of the first

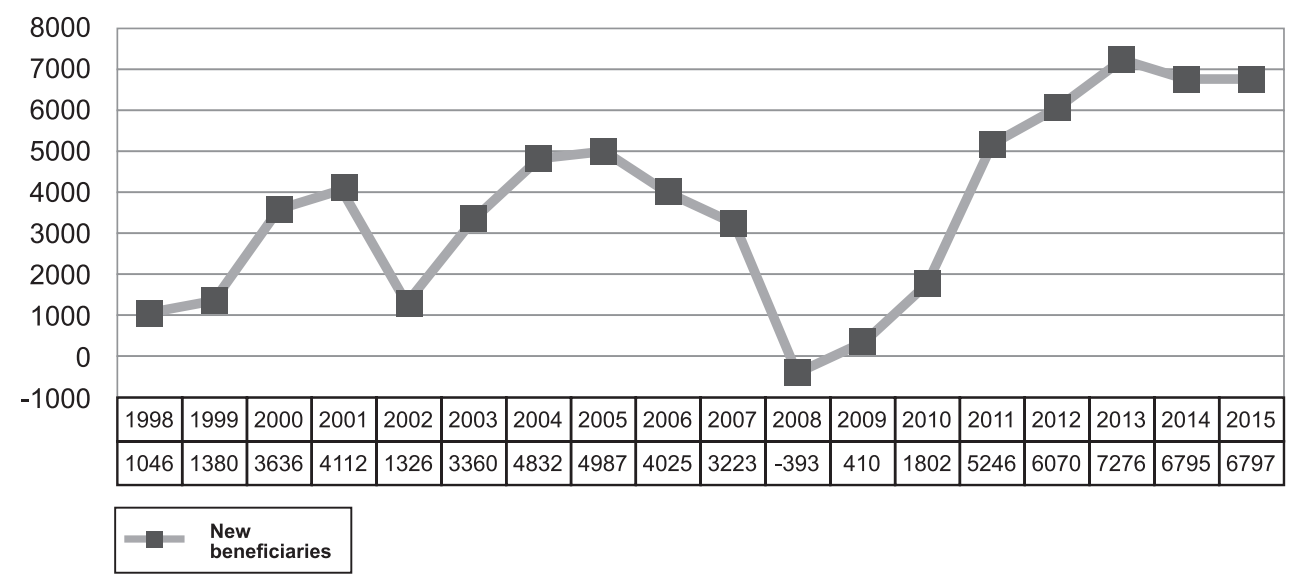

Figure 4 The influx of new age pension users in the period from 1998 to 2015 


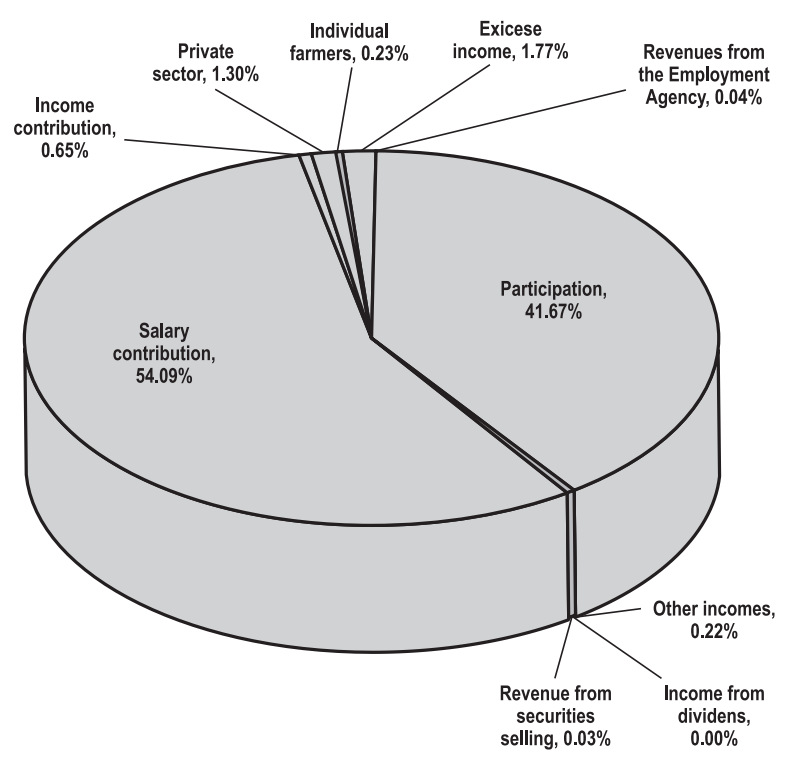

Figure 5 The income Structure

Source: PDIFM, 2016, 33

public pension pillar. According to a conservative scenario, pension deficiency will have been $10.5 \%$ of the GDP by 2030. An implicit pension debt is projected to be over $400 \%$ of the GDP, which is much higher than the European standard. The obligations created by the non-financed pension diagram for future pensions to be paid are called an implicit pension debt. These future promises are demands from a future GDP of a country (van Kamiel, 2014, 9). A high implicit pension debt (IPD) could have serious consequences for the macroeconomic stability and it is a fiscal burden that must not be ignored, especially not so by the countries with high and medium income. The Government could reduce the IPD by increasing the retirement age (Palacios \& Kane, 1996, 38). A permanent increase in budget transfers towards the Fund of the PDIFM, a high implicit pension debt and the fiscal unsustainability of the Fund in the medium and long term point out a need for additional pension reforms. The recommendations for overcoming this problem are given in the following chapter.

\section{DISCUSSION OF THE RESULTS}

The low level of conditions provided for security and health at work points out the fact that the existing legal regulation is not fully applied. The absence of responsibility and care for companies' security and health in the FYR Macedonia is one of the reasons that pose a threat to the health and life of the employed. The unfavorable state in the field of security and health at work could be overcome by

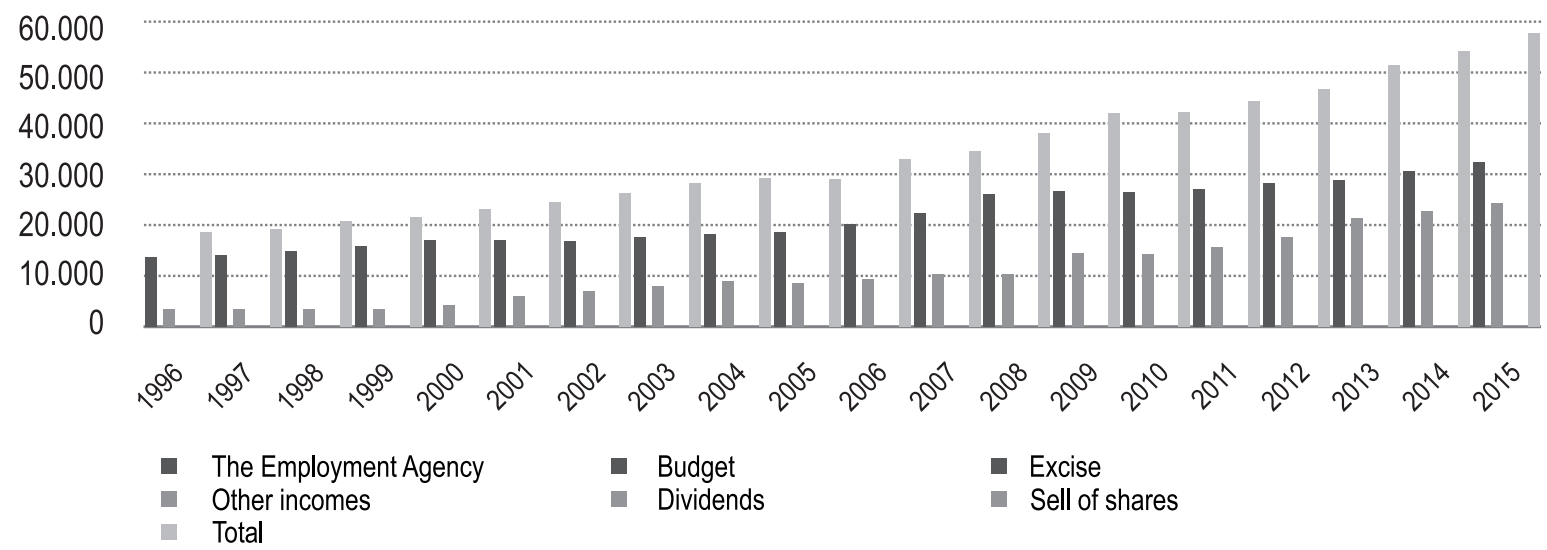

Figure 6 Income fluctuations per years (expressed in Denars - 1 Euro = 61.69 Macedonian denar) 
improving and efficiently applying the regulations in the field of security and health at work and through the promotion of the security and health standards at work. In this context, we would mention the conclusion drawn by the European Commission with respect to the improvement of the FYR Macedonia in this field. That is to say, it was alleged in the Report on the FYR Macedonia for 2015 related to security and health at work that change in the Security and Health at Work Law had to be made and two new books of rules passed, which was not done in consultation with the National Security and Health Council at work, but rather without any previous evaluation of their reconciliation with the European Union Law. The Report also emphasizes that the administrative capacity to provide an appropriate application of the regulations is not sufficient. So, additional reforms are necessary in order to comply with the European Union's Law in this field. Taking into consideration the stated conclusions, it is necessary to revise the regulations in this field by including appropriate institutions competent for the issues of security at work as well as experts from the EU countries, which will enable reconciliation between these regulations and those of the EU. The effective and efficient application of the laws is impossible without the existence of a certain capacity of the administrative services, including inspection supervision over the application of the laws. It implies taking measures and activities so as to increase the capacity in this filed. It is also necessary to find ways how to raise owners' and companies' management's awareness of the benefit the workers could be obtain if they were satisfied and healthy. Organizing workshops and training courses, as well as certain stimulation measures regarding business, could have an impact on the betterment of conditions in this field.

An efficient social policy, social protection and a decrease in unemployment are the fundamental components of decreasing poverty, providing a minimum living standard and a possibility for an active participation of all citizens in a society. The low employment rate, the low income of the employed and enlarged living costs point out that so far the social policy has not been solving a greater part of the social problems that the citizens of the FYR Macedonia are faced with. The European Commission (EC, 2015, 59) recommends that some measures and activities are necessary to take and carry out, respectively, in the field of the social policy and employment in order to raise the employment rate of the young and those who have been unemployed for a long time and provide appropriate institutions and financial resources in order to reduce poverty in the country. To reduce poverty and improve the living standard in the country, it is necessary to increase the minimum and the average net salary of the employed. The sustainability and competition of the domestic and foreign companies should be the Government's priority. This could be achieved by converting a part of the funds from the state budget, from unproductive to capital investments, which would allow a rise in the economic growth of the country, the creation of new jobs and unemployment reduction.

The EU and other countries' experiences in the world indicate the existence of a long-term process of the pension system adaption depending on the changes of the influential factors on their functioning. Modern economic research studies suggested the using of a gradual transfer from the pension system operated on the basis of the generation solidarity principle to and towards the modern private pillars, i.e. relying on the second and the third pension pillars instead of relying on the first public pension pillar. This transfer could be facilitated by providing a simple entry in the private pension plans under such circumstances in which the entry is not conditioned by funding and employment. Future pensioners would have to decide whether they are going to choose the socalled Individual Pension Plans (e.g. the Individual Retirement Account, in the USA, or the Individual Savings Account, in GB) or the so-called Profession or Training Pension Schedules, in which the funds paid in such an account are managed through Trade Unions, Unions, Clusters or Trade Organizations. Some additional activities should also be carried out for the purpose of the development of life insurance as an alternative kind of savings in order to provide 
additional funds to supplement pension income. With the latest changes in the Labor Relations Act in the FYR Macedonia, the retirement age limits are 64 years of age for men and 62 years of age for women, with the opportunity for the employed to decide whether they will have their employment agreement prolonged for yet another three years or not. So, in contrast to other countries, according to our legal changes, the extension of the employment agreement is not a legal obligation, but rather a choice made by an employee. In order to secure the sustainability of the Macedonian Pension System, it is necessary to make changes in relation to an increase in the retirement age limit following the example of the rest of the European countries. This measure could be supplemented with the application of appropriate stimulations in a sort of a monthly pension raise for those who will retire later on or penalties for each month of early retirement. By prolonging the work age, as well as by eliminating a decision on freeing foreign investors from paying tax, pressure on the PDIF of the FYR Macedonia and pressure on the Budget of the FYR Macedonia will both be reduced (Gruevski \& Gaber, 2014).

An efficient health system is essential for achieving general welfare in every country. As directions given with respect to the improvement of the conditions in the Macedonian Health System, the recommendations of the World Bank will be mentioned, according to which, in order to improve their health systems, countries should focus on:

- the improvement of health results;

- better financing, in order to provide sustainable health; and

- the strengthening of the institutional positioning.

The unsatisfactory conditions in Macedonian health point out a need for the urgent diagnosing of the reasons for such bad results in the health system in order to overcome the existing problems. That is why a detailed analysis of the conditions in the health system is necessary, together with their comparing with the regulations and positive practice in European countries.
Only with this kind of a comprehensive approach could reconciliation be achieved in compliance with citizens' real needs and conditions for general human security in the FYR Macedonia created because they are interconnected with each other in a domino effect. It means that any disruption of the conditions in the analyzed segments leads to the deterioration of general human security.

\section{CONCLUSION}

Human security is an important concept referring to the citizens of a society. The concept contains a few key elements referring to the social and political environment, economic development, social and health protection and workplace security, which has a direct impact on the quality of life in a society.

The analysis that has been carried out regarding the conditions in the above-mentioned segments of the public sector in the FYR Macedonia has indicated the fact that the human security concept is very little talked about. Simultaneously, there is no devotion and no political will on institutions' part to implement the European principles of human security that would be used as a guide for a clear formulation of the human security concept in accordance with the Macedonian conditions and the needs of the citizens of the FYR Macedonia.

The FYR Macedonia has been making economic, political, social and other efforts in order to fulfil the obligations for its membership to the EU. In this sense, it is necessary that reforms should be implemented in the Pension System, the Health System and the Social Protection System and that the conditions for the protection and security of workers at their workplaces should be improved, too. From the analysis of the conditions in the focused segments of the public sector, it could be concluded that the reforms which have been implemented have not given the desired effects. The offered measures and the suggested activities with respect to the application of the human security concept in this paper offer opportunities 
to highlight the issues referring to this particular concept. The further ignoring and postponement of a debate over changes in the conditions in the public sector from the aspect of human security could be surpassed by the contribution that could be made by research papers of this kind so that administration could gain know how in order to solve the open issues referring to the clear understanding of human security.

Writing about and debating over the surpassing of the problems in the public sector, however, require transparency and cooperation with public institutions, which, in this case, is missing. Actually, this is the limiting factor of our research.

Our research has confirmed the hypothesis that it is essential to implement profound reforms in the Macedonian Health and Social Sectors, the Pension System and in the field of human security at work in order to achieve a higher level of general human security in the FYR Macedonia.

The research results presented in this work are a motivation factor for conducting future research studies in this field. Our future research studies will give an opportunity to close up numerous open questions, such as: Which strategy should be applied in the FYR Macedonia in order to achieve a general level of human security? Which way should the chosen strategy be used in? Which effects are going to be achieved with the application of the human security concept? Our future research will help to have this concept successfully implemented in the FYR Macedonia.

\section{REFERENCES}

Alli, B. (2008). Fundamentals principles of occupational health and safety. International Labour Office. Geneva.

Devon, A. (2014). Human security concept in political and academic circles. Tehnički glasnik, 8(3), 309-313.

EUROFOUND. (2012). Fifth European Working Conditions Survey. Publications Office of the European Union. Luxembourg.
European Commission. (2015). Report on the Republic of Macedonia for 2015. Brussel.

Eurostat Statistics. (2016a). Retrieved from http://ec.europa. eu/eurostat/statistics-explained/index.php/File:At-riskof_poverty_or_social_exclusion_rate,_2013_and_2014.png

Eurostat Statistics. (2016b). Retrieved from http://ec.europa. eu/eurostat/statistics-explained/index.php/File:Minimum wages,_January_2016_(\%C2\%B9)_(EUR_per_month)_YB16II.png

Grozdanovski, A. et all. (2015). Strategies for improving the safety and health at work Republic of Macedonia through the active participation of civil society organizations, Macedonian association for protection at work. Skopje. Retrieved from http://www.cso-osh.org/images/dok/STRATEGIJA_BZR. pdf

Gruevski, I., \& Gaber, S. (2014, September 11-13). Pension reform globally (general trends and directions). Paper presented at the International scientific conference Social change in the global world, Stip, Macedonia. Retrieved from http:// eprints.ugd.edu.mk/11561/

Health Consumer Power House. (2016). Retrieved from http:// indicators.healthpowerhouse.com/ehci2015-indicators

Mayor, F. (1999). Letters to future generation. France: UNESCO. Retrieved from http://unesdoc.unesco.org/ images/0011/001185/118573E.pdf

Ministry of Labor and Social Policy (2010). National Program for Development of Social Protection: 2011-2020. Skopje.

Ogata, S. (1998). Inclusion or exclusion: Social development challenges for Asia and Europe. Statement of Mrs. S. Ogata, United Nations High Commissioner for Refugees at the Asian Development Bank Seminar. Retrieved from http:// www.unhcr.org/admin/hcspeeches/3ae68fcd54/statementmrs-sadako-ogata-united-nations-high-commissionerrefugees-asian.html

Palacios, R., \& Kane, C. (1996, June). The Implicit Pension Debt. Finance \& Development, 36-38. Retrieved from https:// www.imf.org/external/pubs/ft/fandd/1996/06/pdf/kane.pdf

Pavlovski, B., Antik, D., Friscik, J., Gelevska M., Misev, S., \& Kasapinov, B., (2014). We are all human: Health care for all people regardless of their ethnicity. Health status, health care and the right to health among Roma people in the Republic of Macedonia. Foundation Open Society. Skopje, The Former Yugoslav Republic of Macedonia. 
Pejkovski, J., \& Majovski, I. (n.d.) Reform process and challenges of social policy in Macedonia. Framing a new social policy: actors, dimensions and reforms Friedrich Ebert Foundation, Office of Skopje, The Former Yugoslav Republic of Macedonia.

Pension and Disability Insurance Fund of Macedonia. (2016). Retrieved from http://www.piom.com.mk

PWC. (2014). Social security systems around the globe. Retrieved from https://www.pwc.com/socialsecurity

Social Protection Act, Official Gazette of the Republic of Macedonia. (2009). Retrieved from http://mtsp.gov.mk/ WBStorage/Files/zakon_so_zastita_osnoven.pdf

Sokov, I. (2012). Human security as the universal value. The Journal of Human Security. 8(1), 68-79.

Spicker, P. (2000). The Welfare State: a general theory. London, UK: Sage.

Stanarević, S. (2014). State/national security and human security. Small Guide through the Human Security. Novi Pazar, The Republic of Serbia: Cultural center DamaD.

State Labor Inspectorate. (2016). Retrieved from http://www. dit.gov.mk/godisniIzvestai.php

State Statistical Office. (2014). Macedonia in numbers.
State Statistical Office. (2016). Survey on Income and Living Conditions - 2015.

State Statistical Office. (2016). Wages: News release. Retrieved from http://www.stat.gov.mk/pdf/2016/4.1.16.57.pdf_

Thakur, R. (1997). From National to Human Security, In S. Harris, \& A. Mack (Eds.), Asia-Pacific Security: The Economics, Politics Nexus (pp. 52-80). Sydney, Australia: Allen \& Unwin.

UNESCO. (1999). Letters to Future Generations. United Nations Educational, Scientific and Cultural Organization. Paris, France.

United Nations Development Programme (UNDP). (1994). Human Development Report. New York, NY: Oxford University Press.

van Kamiel, L. (2014). Implicit Pension Debt and Credit Rating: International comparison of implicit pension debts with particular focus on the Netherlands. (Master thesis, Tilburg School of Economics and Management), Retrieved from http://arno. uvt.nl/show.cgi?fid=136220.

Veselinovic, P. (2014). The reforms of the public sector as the key determinant of the transition economy of the Republic of Serbia. Economic Horizons, 16(2), 137-155. doi: 10.5937/ ekonhor1402141V.

\section{Received on $23^{\text {rd }}$ March 2017, after one revision, accepted for publication on $24^{\text {th }}$ April 2017. \\ Published online on $28^{\text {th }}$ April 2017.}

Meri Boshkoska is an Associate Professor at the Faculty of Economics in Prilep, St. Kliment Ohridski, University of Bitola, the Former Yugosalv Republic of Macedonia. She received her PhD in Economics, at the Institute of Economics in Skopje, Ss. Cyril and Methodius, University of Skopje, the Former Yugosalv Republic of Macedonia. Her scientific research interest is focused on international finance and bussines, and financial management. 


\title{
SOCIJALNI I EKONOMSKI ASPEKTI LJUDSKE SIGURNOSTI
}

\author{
Meri Boshkoska \\ Faculty of Economics, Prilep, University St. Kliment Ohridski, Bitola, \\ The Former Yugoslav Republic of Macedonia
}

Cilj ovog rada je analiza stvarnog stanja u oblasti politike zdravlja i socijalne politike Bivše Jugoslovenske (BJ) Republike Makedonije, penzionog sistema i bezbednosti ljudi na radnom mestu. Ovakva analiza će omogućiti donošenje izvesnih zaključaka i preporuka u vezi sa ostvarivanjem višeg nivoa opšte bezbednosti ljudi u BJ Republici Makedoniji. Na osnovu rezultata istraživanja može se zaključiti da su u BJ Republici Makedoniji troškovi života u stalnom porastu, da je stopa nezaposlnosti visoka, da su prosečne isplaćene plate najniže $u$ Regionu, što doprinosi dubokom siromaštvu u zemlji. Neophodno je sprovesti reviziju zakona i regulativa u oblasti zdravlja i bezbednosti zaposlenih, izvršiti hitne izmene u cilju obezbeđivanja održivosti penzionog sistema, i otpočeti sa sprovođenjem reformi koje će omogućiti uspostavljanje održivog i efikasnog sistema zdravstvene zaštite.

Ključne reči: penzioni sistem, socijalna zaštita, stopa siromaštva, sistem zdravstvene zaštite

JEL Classification: 131, 132, H55 